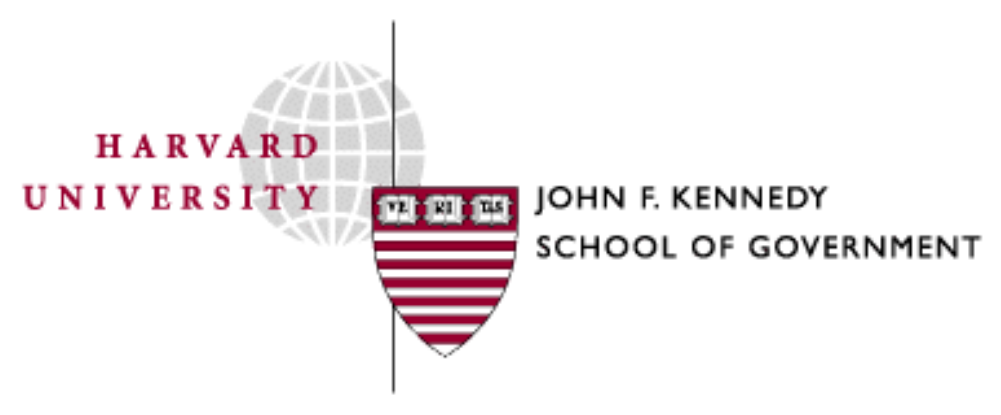

Faculty Research Working Papers Series

\title{
Mobilizing the Party Faithful: Results from a Statewide Turnout Experiment in Michigan
}

\author{
David W. Nickerson, Ryan D. Friedrichs, and David C. King
}

\author{
April 2004 \\ RWP04-018
}

The views expressed in the KSG Faculty Research Working Paper Series are those of the author(s) and do not necessarily reflect those of the John F. Kennedy School of Government or Harvard University. Copyright belongs to the author(s). Papers may be downloaded for personal use only. 


\title{
Mobilizing the Party Faithful:
}

\section{Results from a Statewide Turnout Experiment in Michigan}

\author{
David W. Nickerson \\ Ryan D. Friedrichs \\ David C. King ${ }^{1}$
}

April 1, 2004

\begin{abstract}
Recent large-scale field experiments of get out the vote (GOTV) drives have been non-partisan and may not accurately capture the effectiveness partisan campaign outreach. In the 2002 Michigan gubernatorial election, a large field experiment across 14 state house districts evaluated the cost effectiveness of three mobilization technologies utilized by the Michigan Democratic Party's Youth Coordinated Campaign: door hangers, volunteer phone calls, and face-to-face visits. The results indicate that all three GOTV strategies possess similar cost-effectiveness.
\end{abstract}

\footnotetext{
${ }^{1}$ David W. Nickerson is a Ph.D. candidate in Political Science at Yale University. Ryan D. Friedrichs worked on these experiments as Masters in Public Policy Student at Harvard University's John F. Kennedy School of Government. David C. King is Associate Professor of Public Policy at Harvard University's John F. Kennedy School of Government. We thank the Michigan Democratic Party funding the experiments reported here. We gratefully acknowledge assistance from Don Green, Tom Patterson, Amanda Stitt and the many volunteers who were made available through Michigan's Youth Coordinated Campaign.
} 
How effective are various campaign tactics at bringing voters to the polls? Handbooks for political practitioners emphasize face-to-face contacts and targeted mailings for local campaigns while advocating mass advertising on television and radio for candidates in districts too large to walk (Fauchex 2002, Bike \& Ulmer 2001, Guber 1997). With the number of elected officials in the United States topping 511,000 (U.S. Census 1995), the appetite for guidance on how to attract voters has been strong. Popular manuals on voter turnout have focused on anecdotes from successful campaigns, which reflect fads pushed by paid consultants. This paper builds on experiment-based nonpartisan get-out-the-vote research (Gerber and Green 2000; Gerber and Green 2001; Green, Gerber \& Nickerson 2003) by exploring mobilization on a large scale and within a highly partisan environment: the 2002 Michigan gubernatorial election.

Survey-based scholarship has noted the importance of close elections and strong top-ofthe-ticket draws, but as for what specific things candidates can do to increase turnout, the evidence is less conclusive (Wielhouwer \& Lockerbie 1994; Caldeira, Clausen \& Patterson 1990; Kramer 1970). Personal contact from a campaign is correlated with higher turnout, whether the contact occurs over the phone or face-to-face (Rosenstone \& Hansen 1993). The strength of the links between actions of a campaign and voters are, however, difficult to discern using surveys. Political parties carefully target appeals to people who are already politically active, so those contacted may indeed vote more, but not necessarily because of the contact (Wielhouwer 2003). Furthermore, the mere act of answering a political survey is a political act, and the non-response problem may exaggerate the effect of contacting voters (Brehm 1993).

Field experiments, beginning with Gosnell (1927), divide potential voters into treatment and control groups in order to assess the influence of campaign mailings, phone banking, door knocking, and so on (Eldersveld 1956, Adams \& Smith 1980, Miller, Bositis \& Baer 1981). 
Each of these experiments found a boost in turnout from personal contact, but the sample sizes were small and the experiments failed to account for people in the treatment group who were not contacted (Gerber, Green \& Nickerson 2001).

Recent experiments by Gerber and Green (2000a, 2000b, 2001a, 2001b, 2003) have corrected for deficiencies in earlier studies while including cost estimates of the effectiveness of different turnout techniques (Green, Gerber \& Nickerson 2003; Nickerson forthcoming). Nonpartisan face-to-face canvassing was shown to have the largest effect on turnout (ranging from eight to ten percent, depending on the experiment), while costing from $\$ 12$ to $\$ 20$ per additional vote. For roughly the same cost per additional vote, phone calls from volunteers, which presumably seem more sincere than calls from professional phone bank operators, mobilize three to five percent of the treatment group. In these experiments, professional phone banks proved costly and largely ineffective. Estimates of the costs and effectiveness of get out the vote (GOTV) campaigns have relied on experiments overseen by scholars and run by nonpartisan organizations, such as local Public Interest Research Group (PIRG) chapters. Experiments infusing partisanship into their design are more realistic and may yield results that cannot be captured in nonpartisan environments.

The 2002 Michigan gubernatorial race pitted Republican Lt. Governor Dick Posthumus against Democratic Attorney General Jennifer Granholm. Granholm won with 51\% of the vote. Nearly 3.2 million voters - a record for a non-presidential year - cast ballots. The campaign environment was rich with media attention, while partisan and nonpartisan groups worked to get voters to the polls. The experiments reported below were a part of that widespread get-out-thevote effort on behalf of Granholm. In the sections that follow, we describe the experiments, 
discuss the results, and assess the cost effectiveness of get-out-the-vote techniques in a highlycharged partisan environment.

\section{Design}

Three types of partisan turnout efforts were made in the experiments reported in this paper: door hangers with candidate literature, partisan phone calls, and personal visits from campaign volunteers. The experiments were done through the Michigan Democratic Party's Youth Coordinated Campaign (YCC) in fourteen state house districts. ${ }^{2}$ The Michigan Democratic Party selected districts in which they sensed young people could be most useful for the party in 2002. Organizers used three criteria in making this determination: 1) the size of the Democratic or independent 18-35 year-old voting population, 2) the number of contested races on the ballot, and 3) capacity of the local organizations such as the College Democrats of Michigan or the Michigan Young Democrats.

The voter mobilization studies in this paper use randomized controlled experiments. Within each targeted area, registered voters in Michigan's 2002 voter file were divided randomly into treatment groups that received encouragement to vote and control groups that received no contact from the YCC campaign. The random assignments assure that, on average, the control group is comparable to the treatment groups with regards to measured causes of voting behavior (like age, turnout in past elections, and neighborhood) and unmeasured causes of voting (such as interest in the election, free time on Election Day, and personal relationship with a candidate).

\footnotetext{
${ }^{2}$ Michigan State House districts 4, 6, 21, 23, 26, 52, 53, 54, 55, 60, 62, 75, 94 and 95. These districts included, for example, portions of Ann Arbor, Canton, Detroit, East Lansing, Grand Rapids, Kalamazoo, Royal Oak, Springfield and Woodhaven, among other cities.
} 
To obtain an unbiased estimate of the intent-to-treat-effect, one simply subtracts the voter turnout rate of the treatment group, $Y_{T}$, from that of the control group, $Y_{C}{ }^{3}$

Each of the fourteen sites had a coordinator responsible for the implementation of a GOTV campaign. Differences in geography and institutional capacity made it necessary for some coordinators to focus on one or two of the get-out-the-vote techniques. Thirteen sites successfully completed the experimental protocol for the door hanger experiment; six completed the phone call experiment, and four completed the face-to-face canvassing experiment. ${ }^{4}$ Some potential voters could have been subject to two or more of the tactics, which poses no problem for the analysis because of the randomized nature of the design. Subjects in the treatment and control groups for phone call experiment were equally likely to receive door hangers from the campaign (and vice-versa). Therefore, the other mobilization techniques are merely background noise, just as is the case for the host of other partisan activities in the area not under direction of the experiment. The purpose of the analysis is not to estimate the absolute mobilization effect of phone call or a door hanger in complete isolation from each other. Rather, we estimate the marginal effect of specific get-out-the-vote techniques amidst all the other partisan activities in the state and country.

\footnotetext{
${ }^{3}$ Estimating the boost in turnout from campaign contact is slightly more complicated because not everyone assigned to a treatment group can be contacted. The actual effect of contact from receiving a door hanger or phone call may be larger than the intent-to-treat effect. Adjusting the estimate for actual contact is straightforward. Simply divide the intent-to-treat effect by the contact rate for the given technology, $\gamma$. The estimator of the treatment effect on the subjects treated is, thus, $\frac{Y_{T}-Y_{C}}{\gamma}$. This estimator is equivalent to performing a two-stage least squares regression of vote $(\mathrm{Y})$ on actual contact $(\mathrm{X})$ using randomization $(\mathrm{Z})$ as an instrumental variable (see Appendix $\mathrm{A}$ ). So long as information about the rate at which subjects assigned to the treatment group are actually reached by the campaign for each technology is available, the effect of contact can be accurately estimated. The two-stage least squares estimator also allows for the inclusion of control variables, which can correct for imbalances between treatment and control groups due to chance.

${ }^{4}$ Five sites combined flyers and phone calls. Within the sites that used both flyers and phone calls, so few subjects (roughly 5,000) were eligible for to be treatment group for both that the interaction effects cannot be reliably estimated.
} 
Subjects were drawn from a composite list of registered voters in Michigan. Two outside vendors, who attempted to identify voters' partisan leanings, maintain this list for the state Democratic Party. ${ }^{5}$ The YCC compiled a list of voters who were not Republican (Democrat or Independent or undetermined) who were between the ages of 18 and 35. Registered voters sharing the same address and surname were then placed into households. The resulting list contained 55,472 households and 70,591 registered voters in areas where the experiment was conducted.

Households were randomly assigned to the various treatment conditions. Phone numbers were available for slightly less than half of the homes, and $80 \%$ of these homes were assigned to receive a phone call prior to the election. The households in the phone treatment group were then randomly ordered so that numbers not attempted by the campaign could be rolled into the control group. Sites varied in the amount of effort put towards calling voters, and the final balance between treatment $(10,547)$ and control $(5,634)$ in the phone mobilization experiment was $65 \%-35 \%$.

Treatment and control groups for door hangers and for face-to-face visits were assigned in geographic units based upon the first seven digits of a household's nine-digit zip code. Only those units containing 20 or more eligible households were deemed densely populated enough to warrant walking door-to-door to deliver door hangers and/or conduct face-to-face visits. The efficiency of get-out-the-vote tactics that involve walking is a concern for any campaign, but more so for the YCC, since households with potential Democratic supporters between the ages of

\footnotetext{
${ }^{5}$ Determining the partisan leanings of voters in Michigan has been difficult since the state moved to an open primary system. Because anyone can now vote in party primaries, the state does not keep party identification as part of the qualified voter file. One vendor attempts to weed out voters who identify Republican through the use of surveys. The other vendor focuses upon participation in party primaries as a method of predicting partisan leanings (though McCain's strong support by Democrats in the 2000 Presidential Primary causes a few inferential problems).
} 
18 and 35 are scattered unevenly. Thus, sparsely populated areas were not part of the field experiment.

A map was drawn of targeted areas based upon the first 7 digits of 9 digit zipcodes. Each targeted area was divided randomly into treatment conditions. Sixty percent of the households were assigned to receive a door hanger on in the three days leading up to Election Day. Twothirds of the homes were assigned to receive a knock on the door in the weeks leading up to the election. Areas that did not receive any attempt to deliver the treatment on the part of the campaign were subsequently excluded from the experiment. Restricting the sample in such a manner may raise minor concerns about generalizability, but this way of handling samples in no way biases the results, and contributes to the precision of the estimates.

Face-to-face canvassing campaigns are extremely labor intensive, and our experiment was completed in only four of the sites. Despite the obstacles involved in identifying individuals to solicit and then getting volunteers to the homes, the YCC attempted contact with 4,894 people, leaving 2,458 in the control group. Of those in the treatment group, just 8 percent were actually reached, and, consequently, that portion of the experiment is small and imprecise. The door hanger experiment was much easier to coordinate, and it was completed with 20,186 individuals in the treatment group and 13,336 in the control group. Our results from the door hanger experiment are, as a result, very precise.

The three treatments used are typical of political campaigns. The messages in the phone calls and on the door hangers specifically mentioned the gubernatorial candidate, a high salience office, and stressed voting for the "Democratic ticket." The major difference between the campaign run by the YCC and a regular campaign was the emphasis placed on young people. Two phone scripts were used (see Appendix B). One emphasized issues, while the other one 
informed voters about the location of the nearest polling place. Both scripts were short, informal, and contained many pauses. At two sites, calling began a month before the election; in the other sites, calling began only two weeks prior to the election. The script for door-to-door canvassing was very similar to the phone script (see Appendix C). The door-to-door canvassing was small scale and was scattered through the weeks leading up to Election Day. Door hangers named the statewide and local candidates (see Appendix D). The door hangers were distributed the Saturday, Sunday, and Monday leading up to Election Day.

Before analyzing the results of an experiment, it is important to check whether the treatment and control groups are balanced with regards to observable causes of voting behavior. Randomization ensures that the treatment and control groups are equally likely to vote on average, but any particular randomization may be skewed. While it is possible to control for such imbalances using regression techniques, diagnosing the problem can prevent confusion and suggest the corrective course of action. We found no substantive or significant differences between the treatment and control groups when looking at voting histories, average age, and average year of registration. ${ }^{6}$

Now that the experimental protocol has been described, the treatment regime outlined, and the randomization checked, we are ready to estimate the boost in turnout a voter receives from door hangers, volunteer phone calls, and (to a lesser extent) face-to-face contact. The next section will describe the results for each technology separately.

${ }^{6}$ Table F1

Differences Between Treatment and Control Groups on Observable Traits

\begin{tabular}{|l|l|c|c|c|c|c|}
\hline \multirow{2}{*}{$\begin{array}{l}\text { Door } \\
\text { Hangers }\end{array}$} & Treatment & 20186 & $73.2 \%$ & $23.1 \%$ & 28.6 & Year Registered \\
\cline { 2 - 7 } & Control & 13336 & $73.1 \%$ & $23.1 \%$ & 28.5 & 1999 \\
\hline \multirow{2}{*}{ Phone } & Treatment & 10547 & $79.3 \%$ & $26.4 \%$ & 27.8 & 1999 \\
\cline { 2 - 7 } & Control & 5634 & $79.7 \%$ & $26.8 \%$ & 27.9 & 1999 \\
\hline \multirow{2}{*}{ Face-to-Face } & Treatment & 4894 & $76.6 \%$ & $24.8 \%$ & 27.5 & 1999 \\
\cline { 2 - 7 } & Control & 2458 & $77.2 \%$ & $25.1 \%$ & 27.4 & 1999 \\
\hline
\end{tabular}




\section{Results and Discussion}

\section{Door Hangers}

The largest aspect of the YCC studied experimentally consisted of placing flyers on doors immediately prior to Election Day. ${ }^{7}$ The experiment was run in thirteen state house districts, and contact rates were high because successful "contact" does not require the subject to be home or available. If a volunteer successfully left the flyer on or in the immediate vicinity of the subject's door, it was deemed a "contact." Non-contacts could arise from idiosyncratic factors such as a dog in the yard, but tended to result from secure apartment buildings to which volunteers did not have access or unfamiliar streets the volunteer could not locate (see Table 1, row 6).

\section{Table 1 About Here}

In ten of the thirteen door hanger experiments the treatment group voted at a higher rate than the control group (see Table 1, row 5). The treatment group voted at a $1.2 \%$ greater rate than the control group when all thirteen sites are pooled together. This intent-to-treat effect implies that 12 new votes were created for every 1,000 flyers where delivery was attempted. The fact that the districts that deviate substantially from the $1.2 \%$ intent-to-treat estimate also possess the largest standard errors (because of small sample size and/or low contact rates) suggests that there is little heterogeneity of treatment effect between different sites.

\footnotetext{
${ }^{7}$ The Youth Coordinated Campaign also orchestrated rallies and generated friendly crowds for the gubernatorial candidate to address. Such activities are certainly worthy for a political party and may effect voter turnout, but are difficult to study experimentally and beyond the scope of the current inquiry.
} 
The high contact rate across sites means the treatment-upon-the-treated effect differs little from the intent-to-treat effect. Pooling across all 13 sites where door hangers were studied using precision weighted averages, we find a $1.6 \%$ boost in turnout with a standard error of $0.7 \%$. In other words, for every 1,000 flyers actually delivered, 16 new votes were created. Alternatively, a person in a household receiving a flyer would be $1.6 \%$ more likely to than had she not received the flyer.

These estimates can be made somewhat more precise by including covariates to control for slight imbalances between the treatment and control groups. Table 2 presents the output from the two-stage least squares model described in Appendix A. ${ }^{8}$ The first column offers a base model controlling only for number of subjects in the household and state House district dummies. The estimated boost in turnout from receiving a door hanger on Election Day, $1.5 \%$, is statistically significant and within a standard error of the results from Table 1. Controlling for past voter history (Table 2, column 2) and other demographic variables (Table 2, column 3) do not change the picture substantially. Ultimately, our best estimate is that living in a household where a hanger was delivered boosted turnout by $1.3 \%$.

Table 2 About Here

This result is somewhat surprising in light of the null finding from Gerber and Green (Gerber and Green 2000a). ${ }^{9}$ Because of the larger sample size, greater diversity of geographic regions, and closer approximation of "real" political activities, we feel that our experiment better estimates the true effectiveness of door hangers as a mobilization technology.

\footnotetext{
${ }^{8}$ The linear probability model is presented for the purposes of expositional clarity. Bivariate probit and maximum likelihood models yield identical results. Almost none of the estimated probabilities of voting reside on either extreme, so the likelihood of generating an estimate outside the $0 \%$ to $100 \%$ boundaries is minimal.

${ }^{9}$ Due to the fact that the Michigan voter file does not include party affiliation, we are unable to divide the sample into partisan and independent sub-samples as in Gerber and Green (2000a).
} 


\section{Volunteer Phone Calls}

Unlike the experiment for door hangers, only six of the fourteen state House districts managed to execute the experimental protocol. Not only is phoning more labor intensive than dropping pieces of literature, but space in call centers was difficult to come by for the YCC. ${ }^{10}$ However, the sites that did participate followed the protocol very strictly and the resulting experiment is still among the largest volunteer phone experiments conducted (see Table 3, row 2).

The phone experiment also differed from the door hanger experiment in that contact rates were much lower (see Table 3, row 7). The major cause of the difference is that the phone experiment relied upon subjects answering the phone or possessing an answering machine. A phone call was counted as a "contact" when either a person at the other end of the line picked up the phone and listened to the script or when a message could be left. A subject was not listed as "contacted" when the person answering the phone could confirm that the intended target had moved, there was no answer, or the line was disconnected. We do not believe that leaving a message on an answering machine is as effective as speaking with a person directly. By lumping both modes of delivering the script together, we are providing a conservative estimate of the effect of volunteer phone contact.

In five of the six volunteer phone experiments, voter turnout was higher in the treatment group than the control group. Pooling the six estimates together, we derive an intent-to-treat

\footnotetext{
${ }^{10}$ Rooms with multiple phone lines were already booked by more established campaigns with larger budgets (the total budget for the Youth Coordinated Campaign was \$50,000 and that included salary and health insurance for the paid coordinator). Sufficient phone lines were obtained in areas where the local party heads realized that the YCC represented a very cheap supply of labor.
} 
effect for volunteer phones of $1.6 \%$ (see Table 3, row 4). That is, for every 1,000 phone calls attempted 16 votes were created.

\section{Table 3 About Here}

The effect of a volunteer phone call upon the subjects treated was almost twice as large as the intent-to-treat effect because the contact rate was around 50\%. Young voters are less settled and move more often than more mature voters. Thus, accurate phone numbers are more difficult to come by. After adjusting for the contact rate, one would estimate that receiving a volunteer phone call boosts turnout by $3.2 \%$ (see Table 3, row 8 ). That is, for every 1,000 phone completed, 32 new votes were created.

Controlling for past voter history and demographic features only confirm the efficacy of volunteer phone calls as a partisan mobilization technique. Controlling for past voting history boosts the treatment upon the treated estimate from $3.2 \%$ to $3.5 \%$ (see Table 4, column 2). Adding covariates for age, date of registration, and gender do nothing to change the estimate of $3.5 \%$ (see Table 4, column 3).

\section{Table 4 About Here}

As a point of comparison, $3.5 \%$ is very close to the $3.8 \%$ boost in turnout from volunteer phone calls estimated from the nonpartisan YouthVote experiments (see Nickerson 2004). The replication of a $3.5 \%$ treatment effect suggests that partisan phone calls are not radically different from non-partisan phone calls. In fact, the best guess would be that partisan and non-partisan volunteer phone calls are equally effective. It remains possible that voters are turned on or off by 
calls offering encouragement to vote for a candidate rather than simply vote, but the data does not support such theories of differentiation.

\section{Face-to-Face Canvassing}

Despite the fact that only four sites engaged in door-to-door canvassing, the magnitude of the experiment should have yielded convincing results. Few face-to-face canvassing experiments have involved 7,352 subjects with 4,894 in the treatment group. Assuming a reasonable contact rate of around $30 \%$, the experiment should yield an estimate of the effectiveness of partisan door-to-door canvassing with a standard error of around $4 \%$. Such a standard error would allow us to determine whether partisan canvassing is radically different in efficacy than non-partisan canvassing. Unfortunately, the contact rates in the canvassing experiment were closer to $8 \%$. Thus, the standard errors associated with experimental estimates will be closer to $15 \%$. Since past voter mobilization experiments have found the effect of faceto-face contact to be in the area of $8-12 \%$, a $15 \%$ standard error means the results will merely be suggestive and a direction for further research.

The low contact rates are the result of a number of factors. First, young people move frequently. The contact rate for phoning, which included leaving messages and targeted the slightly more stable voters under age 35 with listed phone numbers, only managed to contact $50 \%$ of the sample, indicating that the list was somewhat outdated. Second, young people are home less often than older voters making it more difficult to find them at home. ${ }^{11}$ Third, canvassers failed to attempt most of the doors listed. Young voters are scattered throughout neighborhoods and difficult to canvass efficiently. The lengthy walk between households

\footnotetext{
${ }^{11}$ Unlike phones, answering machines are not often found at doors.
} 
demoralized canvassers, who seldom completed the walk lists. ${ }^{12}$ Fourth, young voters often live in apartment buildings to which canvassers may not have access. Finally, site captains witnessed the above problems and shifted resources away from face-to-face canvassing in response. As a result, lists did not receive second and third passes to raise the contact rate.

The results of the experiment are consistent with the mobilization effect detected in nonpartisan experiments. Table 5 reports the two-stage least squares estimates of the effect of actual contact. $^{13}$ It appears that face-to-face contact boosted turnout $16.8 \%$ in the treatment group (see Table 5, column 1). Controlling for voter history and demographic features raises the estimate and slightly decreases the standard errors, but the precise effectiveness of face-to-face partisan contact remains cloudy. An eighteen percent point boost in turnout (Table 5, column 2) is substantively higher than the 8-12\% estimate for non-partisan contact, but statistically indistinguishable. We take these results to suggest that partisan canvassing is at least as effective as non-partisan canvassing.

\section{Table 5 About Here}

Now that we have an estimate of the efficacy of each voter mobilization technology, it is possible to calculate relative cost-effectiveness. Face-to-face contact appears to boost turnout more than receiving a door hanger, but it requires far less time to distribute a door hanger than to make a contact in person. The relative ease of a particular mode communication may compensate for less absolute boost in turnout.

The number of contacts made per hour for each technology will vary considerably across time and place. For instance, the speed with which workers can distribute door hangers depends

\footnotetext{
${ }^{12}$ Canvassers may have had some difficulty locating certain addresses as well.

${ }^{13}$ The standard errors associated with each individual site are so enormous ( $15 \%$ is the standard error for the four sites pooled together) that they are barely informative. Thus, the face-to-face results are not broken down by site.
} 
critically upon the layout of the neighborhood. Moving door-to-door to drop off the literature is simply faster in dense urban areas than in suburban or rural regions. Similarly, the number of face-to-face contacts depends upon not only the geography of a neighborhood, but also the social patterns of the populace. People in some neighborhoods are more apt to be home when canvassers knock than in other neighborhoods (and the times when they might be home will vary as well). The assumed contacts per hour used in Table 6 represent the approximate rate of contact for the experiments conducted in Michigan, but the calculation is easy to adapt to the reader's circumstances.

\section{Table 6 About Here}

Assuming that labor costs $\$ 15$ an hour, Table 6 calculates the expense of creating a single vote for door hangers, volunteer phone calls, and face-to-face contact. The table does not take into account the expense of purchasing lists ${ }^{14}$, printing materials ${ }^{15}$, or establishing multiple phone lines. The somewhat surprising conclusion is that volunteer phone calls are the most costeffective means of moving voters to the polls. While Gerber and Green (2000b and 2001a) find professional phone banks are ineffective and therefore not cost effective, we find volunteer phone banks, at $\$ 24$ per vote, to be a relatively cheap way to mobilize voters to the polls. Faceto-face mobilization is only slightly more expensive than volunteer phone calls at $\$ 28$ per vote, but there is a high degree of uncertainty associated with the estimate. While our estimate of the boost in turnout from face-to-face contact may be on the high side, the number of contacts per hour encountered was lower than would be found in many canvassing operations. Young voters

\footnotetext{
${ }^{14}$ The total cost of procuring the voter lists from the two vendors was \$1400. Given the standing relationship between the Michigan Democratic Party and the vendors, the price may be lower than many campaigns would pay.

${ }^{15}$ The cost for designing and printing 100,000 door hangers was $\$ 7300$.
} 
are diffuse and the targeted canvassing was less efficient than a canvassing operation that included all ages of voters.

Surprisingly, door hangers are just as cost-effective a means of increasing turnout as faceto-face contact, costing only $\$ 29$ per vote. While $1.3 \%$ is a not a large boost in turnout, however, hanging literature on a doorknob takes very little time and volunteers can move from door-todoor very quickly. Admittedly, \$29 per vote does not take into account printing costs (about 7.3 cents apiece for the YCC), but there are two good reasons to believe the actual expense in the field may be even lower. First, households will often have more than one voter in residence. Second, dropping off literature is a very low-skill job that involves little contact by volunteers with voters meaning it may be possible to pay less money for the labor involved in delivering door hangers. If we alter the budget calculation to accommodate 1.5 voters seeing each delivered door hanger and a wage rate of $\$ 10$, then our dollars-per-vote estimate for door hanger drops to $\$ 13$ a vote. Thus, in some circumstances door hangers may be the most cost effective means of boosting turnout among supporters.

To understand why this result is so surprising, compare our door hanger result to estimates of the cost-effectiveness of partisan direct mail. Gerber, Green, and Green (2003) estimate that it takes 8 mailings to boost turnout by $1 \%$. At 40 cents a mailing, it would cost a campaign $\$ 320$ to generate a single vote. Even using a more generous non-partisan estimate of 0.5 percentage points for each piece of mail (Gerber and Green 2000b), the dollars-per-vote calculation comes out to $\$ 80$ per vote. In comparison, door hangers are extremely cheap even after accounting for the $\$ 7300$ expense for designing and printing 100,000 door hangers.

Several factors might contribute to a door hanger's larger boost in turnout compared to direct mail. First, timing may account for the differential boost in turnout. Door hangers 
typically arrive a day or two before the Election Day, while the need to send multiple pieces of direct mail to individuals (and the vagaries of the US Postal Service) requires parties to send mail well before Election Day. Second, door hangers arrive isolated from other competing notices and are more likely to be read. Direct mail from parties arrives with the daily mail and is often thrown away with "junk" mail. Finally, a door hanger is slightly more personal than direct mail. While the hanger is clearly printed in bulk, an individual took the time to walk by and place it on a voter's door. The slightly more personal attention may be sufficient to boost turnout in a measurable way.

The reader should not take Table 6 to imply that volunteer phone calls are the best means by which a campaign can boost turnout. Political campaigns will need to adapt their strategies to their surroundings and phones may not always be the appropriate technology. For instance, phone numbers may be available for very few registered voters, in which case door-to-door techniques are more appropriate. Similarly, in an area where many residents screen calls, phone banks may not meet with much success. Our guess is that a combination of techniques is necessary and appropriate.

\section{Conclusion}

The results presented in this paper are the first to use large-scale field experiments to study partisan voter mobilization. Despite the many virtues of the non-partisan experiments conducted by Gerber and Green, the results could not speak to the response from voters to partisan appeals. This paper addresses that gap and suggests that partisan face-to-face and phone voter mobilization drives do not behave differently from non-partisan efforts. The results from 
partisan campaigns are statistically indistinguishable from past non-partisan studies. Thus, it appears that the lessons learned from non-partisan studies can be applied to partisan settings.

The one major point of departure is that door hangers are found to be an effective means of boosting turnout. A boost in turnout of $1.3 \%$ is not enough to swing most elections, but could be a deciding factor in very close elections. At a cost of $\$ 29$ a vote, door hangers are competitive with more personal tactics and can quickly blanket entire neighborhoods. Thus, we believe door hangers are useful arrows in a campaign's quiver.

The door hanger initially appears to contradict the null result from Gerber and Green (2000a). Upon closer inspection, the differences are not wholly incompatible. G\&G find no mobilization for party members, but a very large mobilization effect among unaffiliated voters. Unfortunately, our data do not allow us to replicate this finding since party is not a part of the Michigan voter file. For this reason, the best comparison of the two studies is the results for the overall sample. The non-partisan leaflet used by Gerber and Green produced a $0.8 \%$ percentage point increase (with a standard error of $2.0 \%$, see Table 2 column 1 b) in turnout whereas our larger experiment found a $1.3 \%$ boost (with a standard error of $0.7 \%$ ). Both results are within one standard error of the other and, thus, are not radically different. Because the partisan Michigan experiment is so much larger than the non-partisan Hamden, CT experiment, the precision weighted pooled treatment effect $(1.2 \%$ with a standard error of $0.7 \%)$ is scarcely different from our original partisan finding.

The fact that any treatment effect at all was detected is remarkable given the highly competitive atmosphere surrounding the 2002 gubernatorial election in Michigan, whereas most prior mobilization experiments occurred in uncompetitive elections. The similarity in results suggests that the characteristics of the particular campaign do not determine the effectiveness of 
a voter mobilization technology. Registered voters in Michigan were bombarded with information and messages from both campaigns and the relatively modest efforts of the YCC measurably boosted turnout among targeted individuals.

Modest is an apt description of the Youth Coordinated Campaign. A common complaint of the dollars per vote estimate from field experiments is that the cost of mobilizing voters does not take into account fixed overhead costs. The dollars per vote estimates provided in Table 6 do not take into account any fixed costs that a campaign would incur. The reason for this omission is that such costs will vary from campaign to campaign. However, the efforts of the YCC demonstrate the expenses need not be prohibitive. The total budget for the campaign was $\$ 53,317$, which included all labor, travel, health care, printing, and the purchase of voter lists. Admittedly, the campaign took advantage of volunteer labor and spare office space when possible, but such actions are typical of small-scale political campaigns. The bottom-line is that expense is not the major hurdle to grassroots mobilization for a political campaign.

Several types of studies present themselves as natural extensions of our current research. ${ }^{16}$ The first set of follow up studies concern the external validity of our findings. The Youth Coordinated Campaign focused only upon voters under the age of 35. It is possible that older voters respond differently to blandishments to vote and the proposition is easily tested. The campaign studies supported Democratic candidates. There is little reason to believe that Republican voters and campaigns would behave differently, but verifying this supposition would be useful. The campaign also took place in a tightly contested battle ground state. Perhaps, partisan GOTV drives receive different responses in less competitive regions.

The second set of follow up studies involves refinement on the technology of voter mobilization. While the efficacy of volunteer phone calls and door hangers are established in

\footnotetext{
${ }^{16}$ The door-to-door estimate is very imprecise and replication of the finding would be a simple and worthy project.
} 
this paper, the current analysis offers no evidence on whether the timing is critical to its effectiveness. ${ }^{17}$ Furthermore, it would be useful to see at what point the technique reaches saturation. Gerber, Green, and Green (2003) demonstrate that the effects of direct mail are additive up to a point. Does the finding hold true for door hangers, phone calls, and face-to-face meetings? If so, at what point do each technology reach the point of diminishing returns? The paper also only concerns three technologies a campaign may seek to employ. Experiments on partisan radio and TV advertisements, professional phone banks, and rallies would help to fill in the gaps in the cost effectiveness of campaign strategies.

In all of the tactics described in this paper, the entirety of the interaction between the campaign and the voter takes place in 30 seconds on the phone, at the door, or glancing at a door hanger. Many political consultants insist effective campaigns create a relationship between the voter and the campaign through a series of 6-8 contacts. Contacts repeated over time may differ in character, quality, and effectiveness than essentially anonymous one-shot strategies. The hypothesized difference between campaign types is plausible, but should be tested empirically.

Finally, a study considering the effect of a partisan campaign on vote choice is needed. Political campaigns contact voters for two primary reasons: mobilization and persuasion. Our paper measures the mobilization component as it manifests itself in voter turnout. Presumably, contact from a campaign also persuades an individual to vote for one candidate over another. A study measuring this persuasive component would be immensely interesting to both practitioners and academics.

\footnotetext{
${ }^{17}$ While there was substantial variability in when calls took place, the timing depended upon the organization of the local campaign. It is impossible to disentangle the independent effect of timing and organizational quality.
} 


\section{Appendix A}

This section draws on Green, Gerber and Nickerson 2003.

Let $\mathrm{Y}$ be a dichotomous dependent variable indicating whether a citizen cast a vote, $X \in\{0,1\}$ represent whether the subject was contacted by the campaign for a given technology, and $Z \in\{0,1\}$ indicate whether the subject was assigned to the treatment or control group. Using a linear probability model, the experimental protocol can be represented by the following two equations:

$$
\begin{aligned}
& Y=\alpha+\beta X+\varepsilon_{1} \\
& X=\gamma Z+\varepsilon_{2}
\end{aligned}
$$

The coefficient $\beta$ is the treatment effect (i.e., the boost in turnout that a person receives from contact with the campaign) and the coefficient $\gamma$ is the contact rate (i.e., the probability that the campaigned reached a subject). Through substitution, it is easy to see that $\beta=\frac{Y_{T}-Y_{C}}{\gamma}$. Since Z is randomly assigned, it is uncorrelated with $\varepsilon_{1}$ and a perfect instrument for contact from the campaign, $\mathrm{X}$. Thus, the two equations match the conditions for two-stage least squares. In practice, the two-stage least squares estimator offers identical results to dividing the intent-totreat effect by the contact rate, but it also allows for the addition of control variables, which can correct for imbalances between treatment and control groups due to chance (Angrist, Imbens, and Rubin 1996). 
Appendix B

Phone Scripts

\section{Phone Script 1: Issues}

- Hi, my name is [first name].

- I'm calling from the Youth Coordinated Campaign to ask for your support for

[target campaign] as well as Jennifer Granholm and the rest of the Democratic ticket.

- This is the most important election in decades for Michigan with [issue] and [issue] being debated.

- Young voters can make all the difference in these close elections.

. Can we count on your support on November $5^{\text {th }}$ ?

- Thanks for your time and for more information you can visit [target campaign(s) website]

\section{Phone Script 2: Information}

- Hi, my name is __ [first name].

- I'm calling from the Youth Coordinated Campaign to ask for your support for

[target campaign] as well as Jennifer Granholm and the rest of the Democratic ticket;

- (IF LISTED) And to remind you that your (new) polling location is

- Young voters can make all the difference in these close elections.

. Can we count on your support on November $5^{\text {th }}$ ?

- Thanks for your time and for more information you can visit [target campaign(s) website] 
Appendix C

Door-to-Door Canvassing Script

- Hi, my name is [first name].

- I'm with the Youth Coordinated Campaign and just wanted to give you some information about [target campaign] as well as Jennifer Granholm and the rest of the Democratic ticket.

- This is the most important election in decades for Michigan with [issue] and [issue] being debated. · Young voters can make the difference in these elections. · Can we count on your support on November 5 th? · Thanks for your time. 
Appendix D

Sample Door Hanger
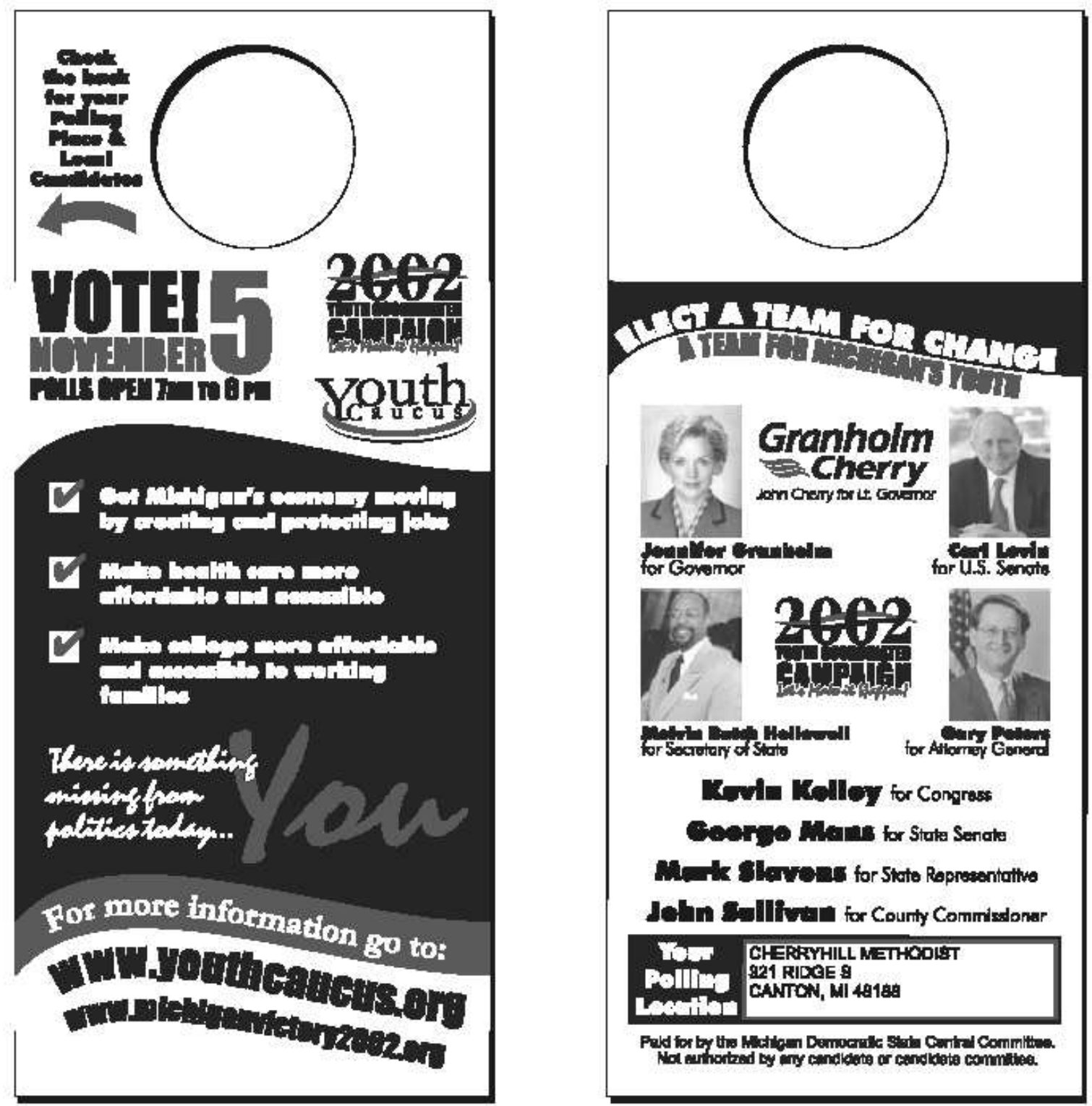
Table 1

Experimental Door hanger Effect Across 13 State House Districts

\begin{tabular}{|l|c|c|c|c|c|c|c|c|c|c|c|c|c|c|}
\hline District & 4 & 6 & 21 & 26 & 52 & 53 & 54 & 55 & 60 & 62 & 75 & 94 & 95 & Pooled \\
\hline $\mathrm{N}$ & 2228 & 3147 & 798 & 3204 & 350 & 1251 & 2086 & 1063 & 1885 & 399 & 1901 & 2941 & 4857 & \\
\hline $\begin{array}{l}\text { Control } \\
\text { Turnout }\end{array}$ & $34.3 \%$ & $31.6 \%$ & $38.4 \%$ & $41.7 \%$ & $7.9 \%$ & $25.2 \%$ & $33.6 \%$ & $32.7 \%$ & $26.5 \%$ & $17.5 \%$ & $48.4 \%$ & $40.2 \%$ & $31.1 \%$ & \\
\hline $\begin{array}{l}\text { Treatment } \\
\text { Turnout }\end{array}$ & $35.3 \%$ & $33.0 \%$ & $32.9 \%$ & $42.6 \%$ & $7.6 \%$ & $26.5 \%$ & $33.8 \%$ & $29.1 \%$ & $27.3 \%$ & $25.3 \%$ & $51.9 \%$ & $43.7 \%$ & $32.9 \%$ & \\
\hline $\begin{array}{l}\text { Intent to } \\
\text { Treat }\end{array}$ & $1.1 \%$ & $1.5 \%$ & $-5.5 \%$ & $0.8 \%$ & $-0.2 \%$ & $1.3 \%$ & $0.1 \%$ & $-3.6 \%$ & $0.8 \%$ & $7.8 \%$ & $3.5 \%$ & $3.5 \%$ & $1.8 \%$ & $1.2 \%$ \\
$(2.1)$ & $(1.7)$ & $(3.5)$ & $(1.8)$ & $(2.9)$ & $(2.5)$ & $(2.1)$ & $(2.9)$ & $(2.1)$ & $(4.3)$ & $(2.3)$ & $(1.9)$ & $(1.4)$ & $(0.6)$ \\
\hline $\begin{array}{l}\text { Contact } \\
\text { Rate }\end{array}$ & $82.0 \%$ & $86.6 \%$ & $84.5 \%$ & $68.2 \%$ & $43.8 \%$ & $54.0 \%$ & $55.2 \%$ & $88.6 \%$ & $60.9 \%$ & $30.5 \%$ & $77.5 \%$ & $84.8 \%$ & $79.3 \%$ & \\
\hline $\begin{array}{l}\text { Estimated } \\
\text { Treatment }\end{array}$ & $1.3 \%$ & $1.7 \%$ & $-6.5 \%$ & $1.2 \%$ & $-0.5 \%$ & $2.4 \%$ & $0.3 \%$ & $-4.1 \%$ & $1.4 \%$ & $25.5 \%$ & $4.5 \%$ & $4.1 \%$ & $2.3 \%$ \\
$(2.0)$ & $(4.2)$ & $(2.6)$ & $(6.7)$ & $(4.7)$ & $(3.8)$ & $(3.3)$ & $(3.4)$ & $(12.8)$ & $(3.0)$ & $(2.2)$ & $(1.7)$ & $(0.7)$ \\
\hline P-value & 0.30 & 0.19 & 0.94 & 0.32 & 0.53 & 0.31 & 0.47 & 0.89 & 0.34 & 0.02 & 0.07 & 0.03 & 0.09 & 0.02 \\
\hline
\end{tabular}

Note: $60 \%$ of subjects were assigned to the treatment group.

$\mathrm{P}$-values are a one-sided test. 
Table 2

Percentage Point Boost in Voter Turnout from Receiving a Door Hanger

\begin{tabular}{|c|c|c|c|}
\hline & Base & Voter History & Demographics \\
\hline Flyer & $\begin{array}{l}1.5^{*} \\
(0.8)\end{array}$ & $\begin{array}{c}1.3^{*} \\
(0.8)\end{array}$ & $\begin{array}{l}1.3^{*} \\
(0.8)\end{array}$ \\
\hline Voted 2000 & & $\begin{array}{c}16.6 * * \\
(0.5)\end{array}$ & $\begin{array}{c}16.1^{* * *} \\
(0.6)\end{array}$ \\
\hline Voted 1998 & & $\begin{array}{c}23.7 * * \\
(0.7)\end{array}$ & $\begin{array}{c}22.5^{* *} * \\
(0.7)\end{array}$ \\
\hline Age & & & $\begin{array}{c}0.5^{* *} * \\
(0.1)\end{array}$ \\
\hline Year Registered & & & $\begin{array}{c}0.5^{* *} \\
(0.1)\end{array}$ \\
\hline Female & & & $\begin{array}{c}0.5 \\
(0.5)\end{array}$ \\
\hline Family Size & & & $\begin{array}{c}10.0^{* *} \\
(0.6)\end{array}$ \\
\hline Constant & $\begin{array}{c}34.5^{* * *} \\
(1.7)\end{array}$ & $\begin{array}{c}18.7 * * \\
(1.7)\end{array}$ & $\begin{array}{c}-988.2^{* *} \\
(104.3)\end{array}$ \\
\hline $\begin{array}{l}\text { District } \\
\text { Dummies }\end{array}$ & YES & YES & YES \\
\hline $\mathrm{N}$ & 33522 & 33522 & 32879 \\
\hline $\mathrm{R}-\mathrm{Sq}$ & 2.4 & 11.3 & 12.0 \\
\hline
\end{tabular}

Estimates derived from 2SLS using assignment to treatment group as an instrument for contact. Using a one-tailed test, $*$ means $\mathrm{p}<0.05, * *$ means $\mathrm{p}<0.01$.

Numbers in parentheses represent standard errors and were calculated clustering on household. 
Table 3

Experimental Phone Effect for State House Districts

\begin{tabular}{|c|c|c|c|c|c|c|c|}
\hline $\begin{array}{l}\text { House } \\
\text { District }\end{array}$ & 21 & 23 & 55 & 60 & 75 & 94 & Pooled \\
\hline $\mathrm{N}$ & 3585 & 1863 & 1896 & 1497 & 3754 & 3586 & \\
\hline$\% \mathrm{~T}$ & $72.1 \%$ & $52.7 \%$ & $47.5 \%$ & $43.7 \%$ & $74.6 \%$ & $73.3 \%$ & \\
\hline $\begin{array}{l}\text { Control } \\
\text { Turnout } \\
\end{array}$ & $44.8 \%$ & $38.0 \%$ & $31.1 \%$ & $33.6 \%$ & $52.0 \%$ & $43.2 \%$ & \\
\hline $\begin{array}{l}\text { Treatment } \\
\text { Turnout }\end{array}$ & $44.6 \%$ & $39.8 \%$ & $31.4 \%$ & $38.1 \%$ & $52.2 \%$ & $47.4 \%$ & \\
\hline $\begin{array}{l}\text { Intent to } \\
\text { Treat }\end{array}$ & $\begin{array}{c}-0.2 \% \\
(1.9) \\
\end{array}$ & $\begin{array}{l}1.8 \% \\
(2.3) \\
\end{array}$ & $\begin{array}{l}0.4 \% \\
(2.1) \\
\end{array}$ & $\begin{array}{l}4.5 \% \\
(2.5) \\
\end{array}$ & $\begin{array}{l}0.2 \% \\
(1.9) \\
\end{array}$ & $\begin{array}{l}4.2 \% \\
(1.9) \\
\end{array}$ & $\begin{array}{l}1.6 \% \\
(0.8) \\
\end{array}$ \\
\hline $\begin{array}{l}\text { Contact } \\
\text { Rate }\end{array}$ & $48.5 \%$ & $47.8 \%$ & $54.3 \%$ & $43.9 \%$ & $51.6 \%$ & $52.3 \%$ & \\
\hline $\begin{array}{l}\text { Estimated } \\
\text { Treatment }\end{array}$ & $\begin{array}{c}-0.3 \% \\
(3.8)\end{array}$ & $\begin{array}{l}3.7 \% \\
(4.7)\end{array}$ & $\begin{array}{l}0.7 \% \\
(3.9)\end{array}$ & $\begin{array}{c}10.3 \% \\
(5.6)\end{array}$ & $\begin{array}{l}0.3 \% \\
(3.6)\end{array}$ & $\begin{array}{l}8.1 \% \\
(3.6)\end{array}$ & $\begin{array}{l}3.2 \% \\
(1.7)\end{array}$ \\
\hline $\mathrm{P}$-value & 0.53 & 0.22 & 0.43 & 0.03 & 0.47 & 0.01 & 0.03 \\
\hline
\end{tabular}

$\mathrm{P}$-values are for a one-sided test. 
Table 4

Percentage Point Boost in Voter Turnout from Receiving a Volunteer Phone Call

\begin{tabular}{|c|c|c|c|}
\hline & Base & Voter History & Demographics \\
\hline Phone Call & $\begin{array}{l}3.2 * \\
(1.8)\end{array}$ & $\begin{array}{l}3.5^{*} \\
(1.7)\end{array}$ & $\begin{array}{l}3.5^{*} \\
(1.7)\end{array}$ \\
\hline Voted 2000 & & $\begin{array}{c}18.3^{* *} \\
(0.9)\end{array}$ & $\begin{array}{c}16.9 * * \\
(1.0)\end{array}$ \\
\hline Voted 1998 & & $\begin{array}{c}25.2 * * \\
(0.9)\end{array}$ & $\begin{array}{c}23.8^{* * *} \\
(1.0)\end{array}$ \\
\hline Age & & & $\begin{array}{c}0.6^{* * *} \\
(0.1)\end{array}$ \\
\hline Year Registered & & & $\begin{array}{l}0.3^{*} \\
(0.2)\end{array}$ \\
\hline Female & & & $\begin{array}{c}0.3 \\
(0.8)\end{array}$ \\
\hline Family Size & & & $\begin{array}{c}8.7 * * \\
(1.1)\end{array}$ \\
\hline Constant & $\begin{array}{c}43.2^{* * *} \\
(1.2)\end{array}$ & $\begin{array}{c}21.4^{* *} \\
(1.2)\end{array}$ & $\begin{array}{c}-677.3^{*} \\
(331.5)\end{array}$ \\
\hline $\begin{array}{l}\text { District } \\
\text { Dummies }\end{array}$ & YES & YES & YES \\
\hline $\begin{array}{l}\text { Order Names } \\
\text { Listed on Sheet }\end{array}$ & YES & YES & YES \\
\hline $\mathrm{N}$ & 16181 & 16181 & 16175 \\
\hline $\mathrm{R}-\mathrm{Sq}$ & 2.6 & 11.7 & 12.5 \\
\hline
\end{tabular}

Estimates derived from 2SLS using assignment to treatment group as an instrument for contact. Using a one-tailed test $*$ means $\mathrm{p}<0.05, * *$ means $\mathrm{p}<0.01$.

Numbers in parentheses represent standard errors and were calculated clustering on household. 


\section{Table 5}

Percentage Point Boost in Voter Turnout from Face-to-Face Contact Across 4 State House Districts

\begin{tabular}{|c|c|c|c|}
\hline & Base & Voter History & Demographics \\
\hline Door Knock & $\begin{array}{c}16.8 \\
(15.9)\end{array}$ & $\begin{array}{c}19.6 \\
(14.9)\end{array}$ & $\begin{array}{c}18.1 \\
(14.8)\end{array}$ \\
\hline Voted 2000 & & $\begin{array}{c}18.1^{* *} \\
(1.2)\end{array}$ & $\begin{array}{c}15.5^{* *} \\
(1.3)\end{array}$ \\
\hline Voted 1998 & & $\begin{array}{c}26.4^{* *} \\
(1.5)\end{array}$ & $\begin{array}{c}23.9 * * \\
(1.5)\end{array}$ \\
\hline Age & & & $\begin{array}{c}0.8 * * \\
(0.1)\end{array}$ \\
\hline Year Registered & & & $\begin{array}{l}-0.1 \\
(0.3)\end{array}$ \\
\hline Female & & & $\begin{array}{l}-1.1 \\
(1.1)\end{array}$ \\
\hline Family Size & & $\begin{array}{c}11.0 * * * \\
(1.5)\end{array}$ & $\begin{array}{c}10.3 * * \\
(1.7)\end{array}$ \\
\hline Constant & $\begin{array}{c}34.9 * * \\
(1.5)\end{array}$ & $\begin{array}{c}17.2 * * \\
(1.5)\end{array}$ & $\begin{array}{c}122.5 \\
(540.5)\end{array}$ \\
\hline $\begin{array}{l}\text { District } \\
\text { Dummies }\end{array}$ & YES & YES & YES \\
\hline $\begin{array}{l}\text { Order Names } \\
\text { Listed on Sheet }\end{array}$ & YES & YES & YES \\
\hline $\mathrm{N}$ & 7352 & 7352 & 7352 \\
\hline $\mathrm{R}-\mathrm{Sq}$ & 3.4 & 13.5 & 14.8 \\
\hline
\end{tabular}

Estimates derived from 2SLS using assignment to treatment group as an instrument for contact. Using a one-tailed test, $*$ means $\mathrm{p}<0.05, * *$ means $\mathrm{p}<0.01$.

Numbers in parentheses represent standard errors and were calculated clustering on household. 
Table 6

Dollars per Vote at \$15 Wage Rate for Voter Mobilization Technologies

\begin{tabular}{|l|c|c|c|}
\hline & $\begin{array}{c}\text { Boost in Turnout from } \\
\text { Contact }\end{array}$ & Contacts Per Hour & $\begin{array}{c}\text { Dollars per Vote } \\
\text { Created }\end{array}$ \\
\hline Door Hanger & $1.3 \%$ & 40 & $\$ 29$ \\
\hline Volunteer Phone Call & $3.5 \%$ & 18 & $\$ 24$ \\
\hline Face-to-Face & $18.1 \% *$ & 3 & $\$ 28$ \\
\hline
\end{tabular}

* Estimate for face-to-face contact is not precise. 


\section{Bibliography}

Adams, William C., and Dennis J. Smith. 1980. "Effects of Telephone Canvassing on Turnout and Preferences: A Field Experiment." Public Opinion Quarterly, 44:389-95.

Angrist, Joshua D., Guido W. Imbens \& Donald B. Rubin. 1996. "Identification of Casual Effects Using Instrumental Variables.” Journal of the American Statistical Association. 91:444-55.

Bike, William S. \& Fran Ulmer. 2001. Winning Political Campaigns : A Comprehensive Guide to Electoral Success. $2^{\text {nd }}$ Edition. Denali Press.

Blydenburgh, John C. 1971. "A Controlled Experiment to Measure the Effects of Personal Contact Campaigning." Midwest Journal of Political Science. 15:365-81.

Brehm, John. 1993. The Phantom Respondents: Opinion Surveys and Political Representation. Ann Arbor: University of Michigan Press.

Cain, Bruce E., and Ken McCue. 1985. "The Efficacy of Registration Drives." Journal of Politics. 47:1221-30.

Caldeira, Gregory A., Aage R. Clausen \& Samuel C. Patterson. 1990. "Partisan Mobilization and Electoral Participation." Electoral Studies, 9:191-204.

Eldersveld, Samuel J. 1956. "Experimental Propaganda Techniques and Voting Behavior." American Political Science Review. 50:154-65.

Eldersveld, Samuel J., and Richard W. Dodge. 1954. "Personal Contact or Mail Propaganda? An Experiment in Voting \& Attitude Change.” Public Opinion and Propaganda, ed. Daniel Katz, Dorwin Cartwright, Samuel Eldersveld, and Alfred M. Lee. New York: Dryden.

Fauchex, Ronald A. 2002. Running for Office: The Strategies, Techniques, and Messages Modern Political Candidates Need to Win Elections. M. Evans \& Co.

Gerber, Alan S., and Donald P. Green. 2000a. "The Effect of a Nonpartisan Get-Out-The-Vote Drive: An Experimental Study of Leafleting.” The Journal of Politics 62:846-857.

Gerber, Alan S. and Donald P. Green. 2000b. "The Effects of Canvassing, Telephone Calls, and Direct Mail on Voter Turnout: A Field Experiment." American Political Science Review 94:653-63.

Gerber, Alan S., and Donald P. Green. 2001a. "Do Phone Calls Increase Voter Turnout? A Field Experiment.” Public Opinion Quarterly 65:75-85.

Gerber, Alan S., and Donald P. Green. 2001b. "Getting Out the Youth Vote: Results from Randomized Field Experiments." Unpublished report to the Pew Charitable Trusts and Yale University's Institute for Social and Policy Studies, December 29, 2001. 
Gerber, Alan S., and Donald P. Green. 2003. "Mobilizing African Americans Using Mail and Commercial Phone Banks: A Field Experiment." Unpublished report, ISPS, Yale University, January 22003.

Gerber, Alan S., Donald P. Green, and Matthew N. Green. 2003. "The Effects of Partisan Direct Mail on Voter Turnout." Electoral Studies, 22:563-79.

Gerber, Alan S., Donald P. Green \& David W. Nickerson. 2001. "Testing for Publication Bias in Political Science." Political Analysis, 9:385-92.

Gosnell, Harold F. 1927. Getting-Out-The-Vote: An Experiment in the Stimulation of Voting. Chicago: University of Chicago Press.

Green, Donald P.\& Alan Gerber. 2002. "Reclaiming the Experimental Tradition in Political Science", in Milner \& Katznelson, eds., State of the Discipline III, Norton.

Green, Donald P., Alan S. Gerber \& David W. Nickerson. 2003. "Getting Out the Vote in Local Elections: Results from Six Door-to-Door Canvassing Experiments." Journal of Politics, 65:1083-96.

Guber, Susan.1997. How to Win your $1^{\text {st }}$ Election. $2^{\text {nd }}$ edition. Saint Lucie Press.

Huckfeldt, Robert, and John Sprague. 1992. "Political Parties and Electoral Mobilization: Political Structure, Social Structure, and the Party Canvass." American Political Science Review, 86:70-86.

Kramer, Gerald H. 1970. "The Effects of Precinct-Level Canvassing on Voting Behavior." Public Opinion Quarterly, 34:560-72.

Lupfer, Michael, and David E. Price. 1972. "On the Merits of Face-to-Face Campaigning." Social Science Quarterly, 53:534-43.

Miller, Roy E., David A. Bositis, and Denise L. Baer. 1981. "Stimulating Voter Turnout in a Primary: Field Experiment with a Precinct Committeeman." International Political Science Review, 2:445-60.

Nickerson, David W., Forthcoming. "Hunting the Elusive Young Voter." The Journal of Political Marketing.

Nickerson, David W. 2004. "Phone Calls Can Increase Turnout." Unpublished Manuscript. Yale University's Institute for Social and Policy Studies.

Rosenstone, Steven J. and John Mark Hansen. 1993. Mobilization, Participation, and Democracy in America. New York: Macmillan, 
Sanbonmatsu, Kira. 2002. "Gender Stereotypes and Vote Choice.” American Journal of Political Science, 46:20-34.

United States Census. 1995. "Number of Elected Officials Exceeds Half Million." Press Release cb95-18. January 30, 1995.

Wielhouwer, Peter W. 2003. "In Search of Lincoln's Perfect List: Targeting in Grassroots Campaigns." American Politics Research, 31:632-69.

Wielhouwer, Peter W., and Brad Lockerbie. 1994. "Party Contacting and Political Participation." American Journal of Political Science, 38:211-29. 